\title{
Agricultural soybean and corn calendar based on moderate resolution satellite images for southern Brazil
}

\section{Calendário agrícola de soja e milho baseado em imagens de satélite de moderada resolução para o sul do Brasil}

\author{
Willyan Ronaldo Becker ${ }^{1 *}$; Jonathan Richetti²; Erivelto Mercante ${ }^{3}$; \\ Júlio César Dalla Mora Esquerdo ${ }^{4}$; Carlos Antonio da Silva Junior ${ }^{5}$; Alex Paludo ${ }^{1}$; \\ Jerry Adriani Johann ${ }^{3}$
}

\section{Highlights:}

Remote sensing techniques can estimate spatially and temporally the seasonal crop dynamics. Seasonal trend can improve yield estimation accuracy and crop forecast models.

Harvest date information contribute to logistics and management of grain receipt in storage units.

\begin{abstract}
Knowledge of the agricultural calendar of crops is essential to better estimate and forecast the cultivation of large-scale crops. The aim of this study was to estimate sowing date (SD), date of maximum vegetative development (DMVD), and harvest date (HD) of soybean and corn in the state of Paraná, Brazil. Dates from 120 farms and the Enhanced Vegetation Index (EVI) from the Moderate Resolution Imaging Spectroradiometer (MODIS) from 2011 to 2014 were used into a seasonal trend analysis to obtain soybean and corn seasonal patterns. The results indicate that the majority soybean is sown during October and the DMVD occurs between the second ten-day period of December and the first ten-day period of January. Owing to the spatial variability of the SD, the difference in the maturation cycles of the cultivars, and regional climatic variation, the HD of soybean varied greatly during the studied crop years, ranging from mid-February to late March. The SD of corn is before that of soybean, and mainly occurs in late September to mid-October. The DMVD mainly occurs during December, and the HD is distributed throughout January to March in Paraná. When comparing the estimated dates with observed dates the mean error (ME) varied from 0.2 days earlier to 3.3 days after the observed date for soybean with root mean square error (RMSE) from 1.93 to 14.73 days. For corn, the ME varied from 10.3 days to 18.5 days after the observed date with RMSE from 18.02 to 27.82 days.
\end{abstract}

Key words: Enhanced Vegetation Index. Timesat. Sowing Date. Harvest Date.

1 Discentes do Curso de Doutorado do Programa de Pós-Graduação em Engenharia Agrícola, PGEAGRI, Universidade Estadual do Oeste do Paraná, UNIOESTE, Cascavel, PR, Brasil. E-mail: willyan.becker@unioeste.br; alex.paludo@unioeste.br

2 Pesquisador Dr., Núcleo de Pesquisa em Geotecnologias e Ciência de Dados, GeoScience, UNIOESTE, Cascavel, PR, Brasil. E-mail: jonathan.richetti@unioeste.br

3 Profs. Drs., PGEAGRI, UNIOESTE, Cascavel, PR, Brasil. E-mail: erivelto.mercante@unioeste.br; jerry.johann@unioeste.br

4 Pesquisador Dr., Empresa Brasileira de Pesquisa Agropecuária, EMBRAPA, Campinas, SP, Brasil. E-mail: julio.esquerdo@ embrapa.br

5 Prof. Dr., Laboratório de Geotecnologia Aplicada em Agricultura e Floresta, GAAF, Universidade do Estado do Mato Grosso, UNEMAT, Cáceres, MT, Brasil. E-mail: carlosjr@unemat.br

* Author for correspondence 


\section{Resumo}

O conhecimento do calendário agrícola das culturas é essencial para melhor estimar e prever o cultivo de culturas em larga escala. O objetivo deste estudo foi estimar a data da semeadura (SD), a data de data de maximo desenvolvimento vegetativo (DMVD) e a data da colheita (HD) de soja e milho no estado do Paraná, Brasil. Datas de 120 fazendas e o Índice de Vegetação Aprimorado (EVI) do Espectrorradiômetro de Imagem de Resolução Moderada (MODIS) de 2011 a 2014 foram utilizados em uma análise de tendência sazonal para obter padrões sazonais de soja e milho. Os resultados indicam que a maioria da soja é semeada em outubro e a DMVD ocorre entre o segundo decêndio de dezembro e o primeiro decêndio de janeiro. Devido à variabilidade espacial do SD, à diferença nos ciclos de maturação das cultivares e à variação climática regional, a HD da soja variou bastante durante as safras estudadas, variando de meados de fevereiro a final de março. A SD do milho é anterior a da soja e ocorre principalmente no final de setembro a meados de outubro. O DMVD ocorre principalmente em dezembro e a HD está distribuída entre janeiro e março no Paraná. Ao comparar as datas estimadas com as datas observadas, o erro médio (ME) variou de 0,2 dias antes a 3,3 dias após a data observada para a soja com a raiz do erro quadrático médio (RMSE) de 1,93 a 14,73 dias. Para o milho, o ME variou de 10,3 dias a 18,5 dias após a data observada, com RMSE de 18,02 a 27,82 dias.

Palavras-chave: Índice de Vegetação Melhorado. Timesat. Data de Semeadura. Data de Colheita.

Soybean is one of the most-grown agricultural crop produced in Brazil, covering 36,790,700 ha and corresponding to $60 \%$ of the national agricultural area, being Paraná responsible for almost 15\% of Brazilian soybean area (Companhia Nacional de Abastecimento [CONAB], 2019). Soybean production in Parana is comparable to national crop levels, with enough cultivated area and production to be among the five largest producers worldwide (United States Departament of Agriculture [USDA], 2019). Corn is the second most-grown agricultural crop in Brazil covering 17,544,100 ha, with Paraná being responsible for $14.7 \%$ of the Brazilian corn area (CONAB, 2019). Such crop information are provided by official Brazilian agencies such as the National Supply Company (CONAB), the Brazilian Institute of Geography and Statistics (IBGE), and the Paraná State Department of Agriculture and Supply (SEAB/DERAL). Although these agencies have adopted geotechnologies in their estimations, a large portion of the data are still obtained through questionnaires ( Instituto Brasileiro de Geografia e Estatistica [IBGE], 2002). The traditional methods used are time and labor intensive, and does not consider the spatial distribution of the croplands. Therefore, delaying the agricultural production information and impairing the effectiveness of any crop forecasting system and compromising logistic planning by companies and the commercialization of commodities.

Early information on crop cycle can allow the optimization of agro-industrial logistics and management, as well as create competitive advantages for industries (Cima, Uribe-Opazo, Johann, Rocha, \& Dalposso, 2018), e.g. the knowledge of regional grain receiving dates. This information and can be estimated with different methods, for example, Mathison, Deva, Falloon and Challinor (2018) estimated the crop sowing and harvest dates for rice and wheat using the Asian summer monsoon onset and retreat obtaining windows from 2.5 to 15 days. Ren, Campbell and Shao (2017)management, planning, and decisionmaking. This study used $250 \mathrm{~m} \mathrm{16-day} \mathrm{Moderate}$ Resolution Imaging Spectroradiometer (MODIS used 16-day MODIS EVI time-series data to detect soybean and corn crop sowing and harvest dates across the Midwestern United States from 2007 to 2015 obtaining root-mean-square error (RMSE) values were 4.81 and 5.30 days for corn and soybean, respectively. 
Such information provides crop spatial and temporal variability can be assessed together with the climatic variables providing insights regarding final grain production. Also, these information are important to companies' logistics that receive grains and for crop modeling, for example, Terler, Gruber and Knaus (2017) studied the effect of variety and harvest date on nutritive value and ruminal degradability of ensiled corn ears concluding that harvest date affects more than the variety. Richetti et al. (2018) used MODIS EVI into machine learning algorithms to estimate soybean in Paraná and showed that EVI around date of maximum vegetative development are most influential to yield response.

Therefore, the aim of this study is to apply a seasonal trend analysis to estimate the sowing date (SD), date of maximum vegetative development (DMVD), and harvest date (HD) for soybean and corn crops in the state of Paraná using satellite images in a pixel scale. Specific objectives were: 1) identify TIMESAT threshold values for the region 2) analyze spatial patterns of SD, DMVD, and HD based on MODIS-derived results.

The study area consists in the state of Paraná, southern Brazil, located between the $22^{\circ} 29^{\prime} \mathrm{S}$ and $26^{\circ} 43^{\prime} \mathrm{S}$ parallels and the $48^{\circ} 02^{\prime} \mathrm{W}$ and $54^{\circ} 38^{\prime} \mathrm{W}$ meridians, with an area of $199,554 \mathrm{~km}^{2}$. Paraná's climate falls into four types according to regions within its territory: $\mathrm{Aw}, \mathrm{Cfa}, \mathrm{Cfb}$ and $\mathrm{Cwa}$ (Aparecido, Rolim, Richetti, Souza, \& Johann, 2016).

A total of 120 farms cultivating soybean and corn were used from 2011 to 2014, totaling 14,170 ha of soybean and 1,681 ha of corn, which sowing and harvest dates were obtained. Brazilian summer crops such as soybean and corn are sown in the end of a year and harvested in the beginning of the following year. In the studied period, 102 EVI images from MOD13Q1 and MYD13Q1 products in the tile $h 13 \mathrm{v} 11$, with a spatial resolution of 250 meters and combined temporal resolution of 8 days were used. In addition, mapped soybean and corn from Souza, Mercante, Johann, Lamparelli and Uribe-Opazo (2015) and Grzegozewski, Johann, Uribe-Opazo, Mercante and Coutinho (2016) were used.

The flat-bottom smoothing filter proposed by Wardlow, Kastens and Egbert (2006) was applied to the MODIS time series to minimize the influence of residual noise. This filter replaces inconsistent data with the smallest adjacent value in the time series, thus minimizing possible failures during the crop cycle. To smooth the temporal EVI profiles, the Savitzky-Golay filter was used. The Timesat software (Eklundh \& Jönsson, 2015) was used to conduct the seasonal trend analysis (STA). The STA consist in identifying the start and end points of the seasonal cropping cycles and calculate phenological metrics from them (Eklundh \& Jönsson, 2015; Johann, Becker, Uribe-Opazo, \& Mercante, 2016). These procedures were done for each crop for each season, resulting in Sowing Date (SD), Harvest Date (HD) and Date of Maximum Vegetative Development (DMVD). The parameters required in Timesat used were 0.022 and 0.105 for the start and end of season, respectively, for soybean, and 0.0775 and 0.150 for the start and end of season, respectively, for corn. The results were compared with reports from official departments. In addition, the mean error (ME) and root square mean error (RMSE) was calculated with the results and observed dates from the farms.

The preferential sowing period for soybean varies from October 25 to December 5, in which the sowing season is commonly subdivided into anticipated (sown in October), normal (sown in November), and late soybean (sown in December). Figure 1 shows ten-day difference in SD, DMVD, and HD for the state during the studied seasons. The dates vary and depend on the characteristics of each region. The western region plants and harvests first and the more east the later, the soybean is sown. Accordingly, the DMVD and HD follows the same pattern. Field data indicate that this region, 
in general, do two annual crops in the summer and a soil cover crop in the winter, e.g. oat, vetch and brachiaria, to maintain and improve the no-tillage system. They also indicate that summer crops, should be short to avoid prolonging until possible frost periods that could affect the second crop. Thus, agro-climatic zoning, especially for the second summer crop, recommends early planting in order to avoid risky periods. These results are similar to those obtained by Johann et al. (2016) and Becker, Johann, Richetti and Silva (2017). However, they retrieved dates from soybean areas in a municipality level, while this study shows by pixel scale.

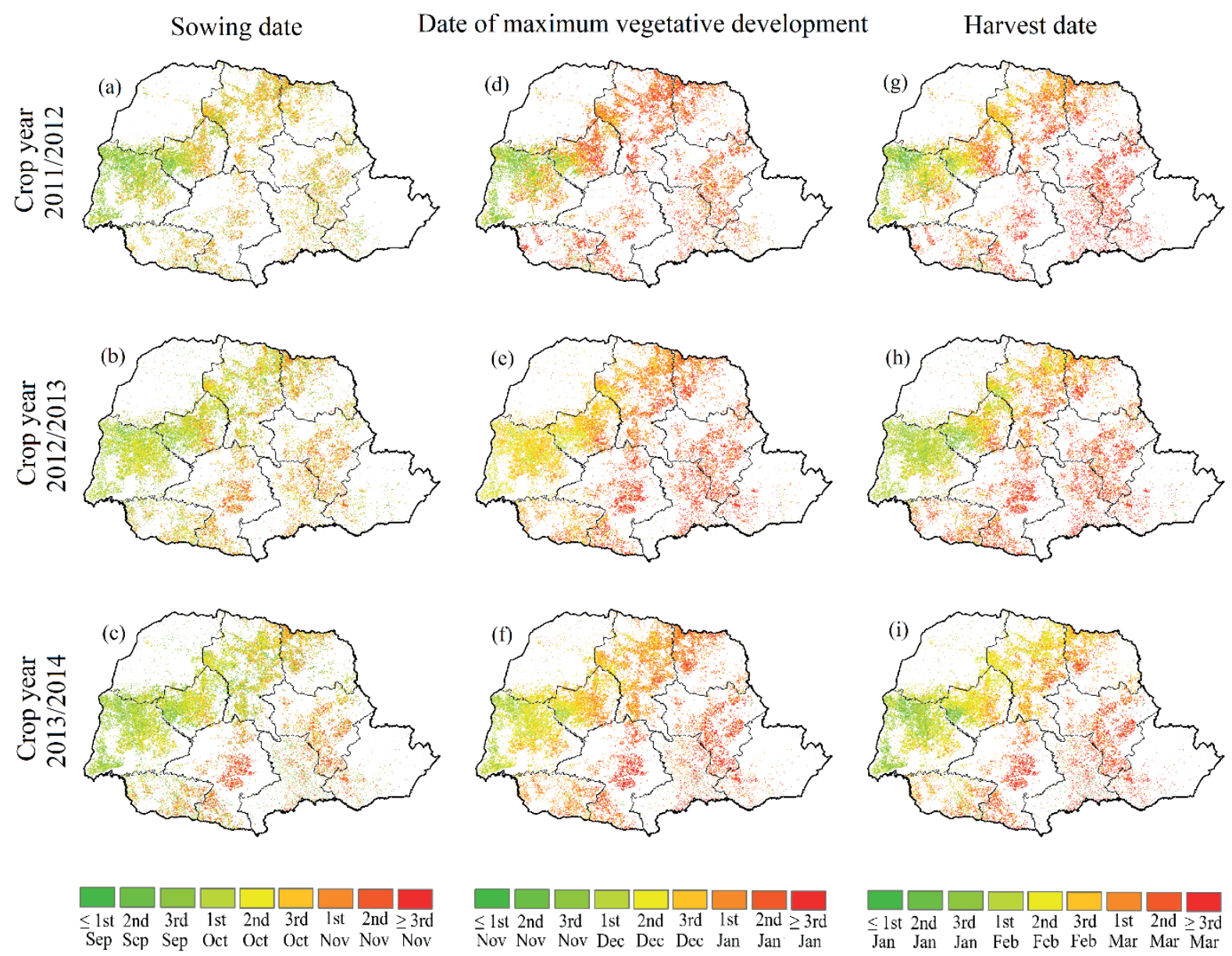

Figure 1. Estimated soybean sowing date (SD), date of maximum vegetative development (DMVD) and harvest date (HD) for season 2011/2012, 2012/2013, and 2013/2014 in a pixel scale for the state of Paraná. Being, SD for crop year 2011/2012 (a), 2012/2013 (b), and 2013/2014 (c); DMVD for crop year 2011/2012 (d), $2012 / 2013$ (e), and 2013/2014 (f); and HD for crop year 2011/2012 (g), 2012/2013 (h), and 2013/2014 (i).

The SD, DMVD, and HD percentages of area for the whole state and the official SD and HD data obtained from Secretaria da Agricultura e do Abastecimento/Departamento de Economia Rural [SEAB/DERAL] (2019) are presented at Table 1.
According to the official data for the studied crop years, for example, the SD percentage is low in September, which differs from the results of this study. The inverse of this occurs for November; the official information indicates a high percentage of 
sown areas, while the results show few remaining sowing areas. Johann et al. (2016) already noted these differences between the official and estimated satellite data at the municipal scale for the 2011/2012 crop year. These differences could be related to the methodology used by the official agencies, which mainly use data obtained from cooperatives and companies (IBGE, 2002), while the methodology proposed in this study was based on data from monitored farms in Paraná. For example, in the $2012 / 2013$ crop year, the results shown that $19.77 \%$ of the area was sown in September, while SEAB/
DERAL reported 3\% (Table 1). Due to the variability in SD, the different maturation cycles of the cultivars, and the weather variation across the regions, the HD of soybean varied greatly within the crop years, e.g. ranging from mid-February to the end of March in the 2011/2012 crop year (Figure 1g). Similarly to the SD, when comparing the estimated HD with the $\mathrm{SEAB} / \mathrm{DERAL}$ there is divergence. For example, for crop year 2011/2012 the estimated showed that $34.95 \%$ of the area was harvested in February while SEAB/DERAL reported 19\% (Table 1).

Table 1

Percentages of the area estimated and officially reported sowing date (SD), date of maximum vegetative development (DMVD), and harvest date (HD) for soybean

\begin{tabular}{ccccccccccc}
\hline & $\begin{array}{c}\text { Crop } \\
\text { Year }\end{array}$ & $1^{\text {st }}$ Sep & $2^{\text {nd }}$ Sep & $3^{\text {rd }}$ Sep & $1^{\text {st }}$ Oct & $2^{\text {nd }}$ Oct & $3^{\text {rd }}$ Oct & $1^{\text {st }}$ Nov & $2^{\text {nd }}$ Nov & $3^{\text {rd }}$ Nov \\
\hline Estimated & $2011 / 12$ & 11.84 & 2.37 & 13.92 & 16.44 & 10.31 & 27.10 & 11.85 & 3.76 & 2.41 \\
SD $\%$ of & $2012 / 13$ & 6.27 & 4.55 & 8.95 & 23.58 & 21.44 & 14.34 & 12.81 & 5.40 & 2.67 \\
area $)$ & $2013 / 14$ & 9.69 & 4.32 & 12.91 & 18.46 & 19.87 & 13.50 & 10.98 & 5.80 & 4.47 \\
\hline SEAB/ & $2011 / 12$ & & 5 & & & 47 & & & 48 \\
DERAL SD & $2012 / 13$ & & 3 & & & 43 & & & 54 & \\
$(\%$ of area $)$ & $2013 / 14$ & & 2 & & & 45 & & & 53 & \\
\hline & & $1^{\text {st }}$ Nov & $2^{\text {nd }}$ Nov & $3^{\text {rd }}$ Nov & $1^{\text {st }}$ Dec & $2^{\text {nd }}$ Dec & $3^{\text {rd }}$ Dec & $1^{\text {st } J a n}$ & $2^{\text {nd }}$ Jan & $3^{\text {rd }}$ Jan \\
\hline Estimated & $2011 / 12$ & 0.73 & 3.12 & 9.03 & 8.68 & 9.71 & 8.91 & 18.91 & 21.75 & 19.16 \\
DMVD & $2012 / 13$ & 0.41 & 0.13 & 0.87 & 4.37 & 17.55 & 25.80 & 21.33 & 16.04 & 13.49 \\
$(\%$ of area $)$ & $2013 / 14$ & 0.57 & 0.43 & 2.83 & 9.84 & 18.10 & 20.96 & 24.49 & 11.65 & 11.15 \\
\hline & & $1^{\text {st }}$ Jan & $2^{\text {nd }}$ Jan & $3^{\text {rd }}$ Jan & $1^{\text {st }}$ Feb & $2^{\text {nd }}$ Feb & $3^{\text {rd }}$ Feb & $1^{\text {st }}$ Mar & $2^{\text {nd }}$ Mar & $3^{\text {rd }}$ Mar \\
\hline Estimated & $2011 / 12$ & 1.96 & 4.11 & 6.30 & 5.15 & 16.05 & 13.75 & 17.17 & 13.07 & 22.45 \\
HD $(\%$ of & $2012 / 13$ & 0.87 & 0.77 & 7.66 & 18.15 & 18.34 & 9.69 & 12.29 & 15.24 & 16.99 \\
area $)$ & $2013 / 14$ & 1.50 & 2.06 & 8.16 & 11.88 & 26.87 & 16.46 & 12.18 & 7.74 & 13.15 \\
\hline SEAB/ & $2011 / 12$ & & 3 & & & 19 & & & 78 & \\
DERAL HD & $2012 / 13$ & & 1 & & & 38 & & & 61 & \\
$(\%$ of area $)$ & $2013 / 14$ & & 4 & & & 38 & & & 58 & \\
\hline
\end{tabular}

Note: $1^{\text {st }}, 2^{\text {nd }}$, and $3^{\text {rd }}$ are first, second, and third ten-days of the month. SEAB/DERAL is the Paraná State Department of Agriculture and Supply. 
It is important to know the DMVD when using yield estimation models to examine existing problems during the critical stages of crop growth, such as weather events or pests and diseases. Such knowledge is also useful for predicting the HD for each culture from a standard time interval. Furthermore, information on DMVD acts as primary data for crop mapping procedures based on differences in the vegetation index images (Grzegozewski et al., 2016; Johann, Rocha, Duft, \& Lamparelli, 2012).

There is a discrepant difference when comparing estimated dates with reported from official departments, however when comparing the estimated dates with the observed one in the monitored farms the method is much more accurate. The mean error (ME) for soybean SD was 2.6 days, with a root mean square error (RMSE) of 9.49 days in 2011/2012, ME of 3.3 days and RMSE of 7.51 days in 2012/2013 and ME of -0.2 days and RMSE of 12.62 days in 2013/2014. For HD, the 2011/2012 ME was 2.2 days and the RMSE was 7.51, ME of 0.9 days and 1.93 days in 2012/2013 and ME of 1.3 and RMSE of 14.73 days in 2013/2014. It is noteworthy that the maximum ME was 3.3 days for sowing and 2.2 days for harvest when comparing farm data with those estimated by satellite. This demonstrates the excellent accuracy that can be obtained and especially the scalability and replicability with the use of satellite images to obtain data from the phenological cycle of agricultural crops. Ren et al. (2017) management, planning, and decisionmaking. This study used $250 \mathrm{~m}$ 16-day Moderate Resolution Imaging Spectroradiometer (MODIS presented RMSE for soybean from 3.11 to 7.12 days, however they were not compared with farm data, but with the National Agricultural Statistics Service data.

Summer corn is traditionally sown before soybean and commonly divided into three types: early (sown in September), normal (sown in October), and late corn (in November). Figure 2 shows ten-day difference in corn SD, DVMD, and HD for the state during the studied seasons. As expected, the dates vary and depends on the characteristics of each region. The west region planting first than the other regions and most corn is planted in October. Corroborating with Becker et al. (2017) that found that corn SD was concentrated in October, which suggests a temporal preference for corn sowing in this month. The Western and Northwestern mesoregions harvest far ahead of the other regions, followed by the Western Center. A very advanced harvest occurs in March for some mesoregions, such as the Metropolitan of Curitiba and the Southeastern. 


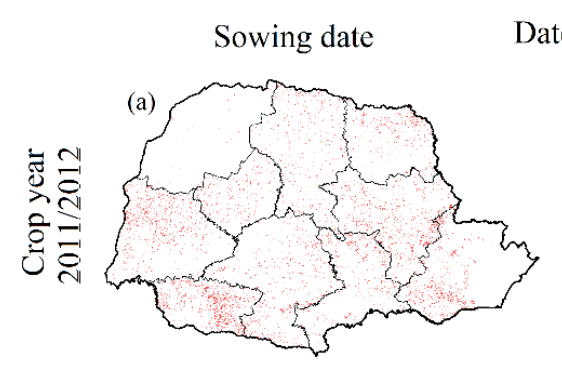

Date of maximum vegetative development

Harvest date
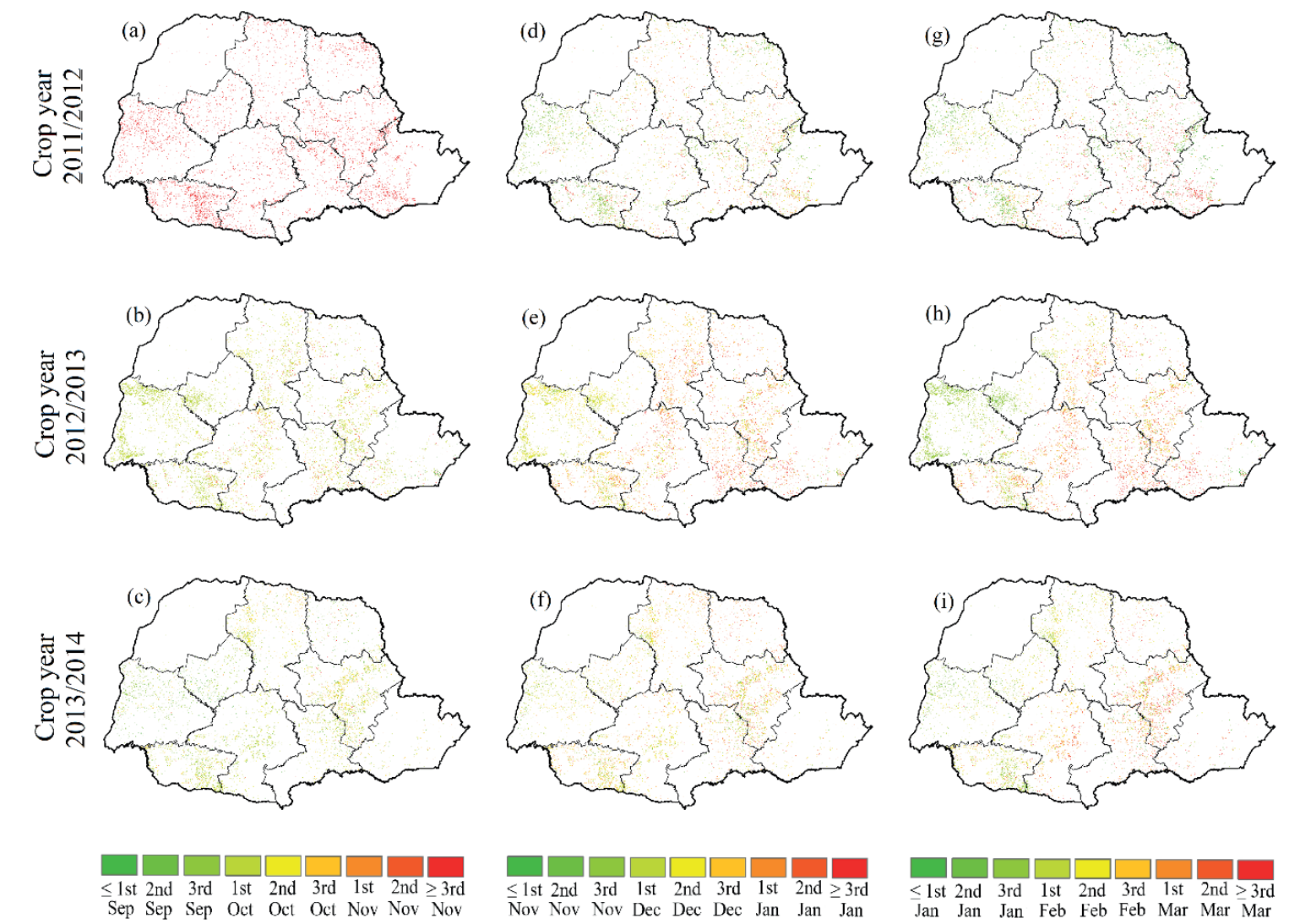

Figure 2. Estimated corn sowing date (SD), date of maximum vegetative development (DMVD) and harvest date (HD) for season 2011/2012, 2012/2013, and 2013/2014 in a pixel scale for the state of Paraná. Being, SD for crop year 2011/2012 (a), 2012/2013 (b), and 2013/2014 (c); DMVD for crop year 2011/2012 (d), 2012/2013 (e), and 2013/2014 (f); and HD for crop year 2011/2012 (g), 2012/2013 (h), and 2013/2014 (i).

Similar to soybean, when comparing estimated corn dates with SEAB/DERAL (2019) data there are divergence. For example, in the crop year $2011 / 2012$, the results shown that $26.52 \%$ of the area was sown in October, while SEAB/DERAL reported $40 \%$ (Table 2). Due to the variability in $\mathrm{SD}$, the different maturation cycles of the cultivars, and the weather variation across the regions, the corn HD also varied greatly within the crop years. Similarly to the SD, when comparing the estimated HD with the SEAB/DERAL there is divergence. For example, for crop year 2011/2012 the estimated showed that $31.07 \%$ of the area was harvested in March while SEAB/DERAL reported 77\% (Table 2 ). Also, the results for corn HD differ greatly from those reported by the official department, especially for corn harvest, which SEAB/DERAL recorded for $1 \%$ or $0 \%$ of the area was harvested in January while the estimated shown 21.2 to $44.29 \%$ depending on the crop year (Table 2).

As already stated, DMVD is important especially for yield estimation and forecast, and, for example, for corn in the crop year 2011/2012 (Figure 2e) $39.51 \%$ and $34.74 \%$ of the area reached its DMVD (Figure 2b) in November and December, respectively. Corn harvest varied across the state, like SD and DMVD. Becker et al. (2017) also observed similar pattern. This is due to the possibility of maintaining corn in the field after it is ready for harvest, which does not apply to other agricultural crops as it could cause grain loss. 
Table 2

Percentages of the area estimated and officially reported sowing date (SD), date of maximum vegetative development (DMVD), and harvest date (HD) for corn

\begin{tabular}{ccccccccccc}
\hline & $\begin{array}{c}\text { Crop } \\
\text { Year }\end{array}$ & $1^{\text {st }}$ Sep & $2^{\text {nd }}$ Sep & $3^{\text {rd }}$ Sep & $1^{\text {st }}$ Oct & $2^{\text {nd }}$ Oct & $3^{\text {rd }}$ Oct & $1^{\text {st }}$ Nov & $2^{\text {nd }}$ Nov & $3^{\text {rd }}$ Nov \\
\hline Estimated & $2011 / 12$ & 30.44 & 7.67 & 26.84 & 18.12 & 4.01 & 4.39 & 4.10 & 1.97 & 2.47 \\
SD $(\%$ of & $2012 / 13$ & 1.63 & 0.93 & 6.90 & 54.41 & 24.07 & 0.75 & 2.83 & 4.91 & 3.57 \\
area $)$ & $2013 / 14$ & 5.59 & 6.32 & 21.41 & 25.57 & 21.84 & 15.88 & 1.88 & 0.41 & 1.10 \\
\hline SEAB $/$ & $2011 / 12$ & & 46 & & & 40 & & & 14 & \\
DERAL SD & $2012 / 13$ & & 26 & & & 60 & & & 14 & \\
$(\%$ of area $)$ & $2013 / 14$ & & 27 & & & 58 & & & 15 & \\
\hline & & $1^{\text {st }}$ Nov & $2^{\text {nd }}$ Nov & $3^{\text {rd }}$ Nov & $1^{\text {st }}$ Dec & $2^{\text {nd }}$ Dec & $3^{\text {rd }}$ Dec & $1^{\text {st }}$ Jan & $2^{\text {nd }}$ Jan & $3^{\text {rd }}$ Jan \\
\hline Estimated & $2011 / 12$ & 8.10 & 13.99 & 17.42 & 13.97 & 12.51 & 8.26 & 10.05 & 7.28 & 8.40 \\
DMVD & $2012 / 13$ & 0.85 & 0.70 & 3.69 & 14.65 & 24.82 & 17.05 & 15.90 & 11.85 & 10.50 \\
$(\%$ of area $)$ & $2013 / 14$ & 0.75 & 2.15 & 9.16 & 18.40 & 23.09 & 19.25 & 16.62 & 6.62 & 3.95 \\
\hline & & $1^{\text {st }}$ Jan & $2^{\text {nd }}$ Jan & $3^{\text {rd }}$ Jan & $1^{\text {st }}$ Feb & $2^{\text {nd }}$ Feb & $3^{\text {rd }}$ Feb & $1^{\text {st }}$ Mar & $2^{\text {nd }}$ Mar & $3^{\text {rd }}$ Mar \\
\hline Estimated & $2011 / 12$ & 21.62 & 11.22 & 11.45 & 9.08 & 9.58 & 5.98 & 5.81 & 5.59 & 19.67 \\
HD $(\%$ of & $2012 / 13$ & 2.32 & 2.90 & 20.13 & 14.62 & 13.86 & 7.60 & 12.16 & 12.79 & 13.62 \\
area $)$ & $2013 / 14$ & 4.79 & 4.46 & 11.95 & 14.24 & 21.79 & 13.99 & 11.87 & 5.91 & 11.01 \\
\hline SEAB $/$ & $2011 / 12$ & & 1 & & & 21 & & & 77 & \\
DERAL HD & $2012 / 13$ & & 0 & & & 19 & & & 81 & \\
$(\%$ of area $)$ & $2013 / 14$ & & 1 & & & 28 & & & 72 & \\
\hline
\end{tabular}

Note: $1^{\text {st }}, 2^{\text {nd }}$, and $3^{\text {rd }}$ are first, second, and third ten-days of the month. SEAB/DERAL is the Paraná State Department of Agriculture and Supply.

As observed for soybean, there is a discrepant difference when comparing estimated dates with reported from official departments, however when comparing the estimated dates with the observed one in the monitored farms the method is more accurate. The mean error (ME) for corn varied from 10.3 days $(2012 / 2013)$ to 18.5 days after the observed date (2013/2014). The root mean square error (RMSE) varied from 18.02 (2012/2013) to 27.82 days $(2013 / 2014)$. Ren et al. (2017) management, planning, and decision-making. This study used $250 \mathrm{~m}$ 16-day Moderate Resolution Imaging Spectroradiometer (MODIS presented RMSE for corn from 2.84 to 6.83 days, however they were not compared with farm data, but with the National Agricultural Statistics Service data.

Therefore, the procedures allowed characterizing and synthesizing the spatial distribution of SD,
DMVD, and HD for soybean and corn in a pixel level. According to the three studied crop years (2011/2012 to $2013 / 2014)$, the soybean SD was mainly concentrated in October; however, in the Western mesoregion of Paraná, it occurs in September while it advances in November in the eastern regions of the state. This pattern is repeated for the DMVD and HD. The SD of corn occurs before that of soybean, and is mainly concentrated during the end of September to mid-October. The DMVD mainly occurs in December and the HD is distributed during January to March in the state of Paraná. When comparing the estimated dates with observed dates the ME varied from 0.2 days earlier to 3.3 days after the observed date for soybean with RMSE from 1.93 to 14.73 days. For corn, the ME varied from 10.3 days to 18.5 days after the observed date with RMSE from 18.02 to 27.82 days. 


\section{Acknowledgments}

This work was supported by the CNPq foundation (National Council for Scientific and Technological Development - Brazil) under grant n. 131314/20157 and by the Fundação Araucária (State of Parana Research Foundation - Paraná - Brazil) under grant 09/2016. Moreover, the authors are grateful to the farmers for sharing their management data.

\section{References}

Aparecido, L. E. de O., Rolim, G. de S., Richetti, J., Souza, P. S. de, \& Johann, J. A. (2016). Köppen, Thornthwaite and Camargo climate classifications for climatic zoning in the State of Paraná, Brazil. Ciência e Agrotecnologia, 40(4), 405-417. doi: 10.1590/1413-70542016404003916

Becker, W. R., Johann, J. A., Richetti, J., \& Silva, L. C. de A. (2017). Data mining techniques for separation of summer crop based on satellite images. Engenharia Agrícola, 37(4), 750-759. doi: 10.1590/1809-4430eng.agric.v37n4p750-759/2017

Cima, E. G., Uribe-Opazo, M. A., Johann, J. A., Rocha, W. F. da, Jr., \& Dalposso, G. H. (2018). Analysis of spatial autocorrelation of grain production and agricultural storage in Paraná. Engenharia Agrícola, 38(3), 395-402. doi: 10.1590/1809-4430-eng.agric. v38n3p395-402/2018

Companhia Nacional de Abastecimento (2019). Acompanhamento da Safra Brasileira de Grãos Safra 2019/20 - Terceiro Levantamento. Brasília. Recuperado de http//www.conab.gov.br/info-agro/ safras/ grãos/boletim-da-safra-de-graos/item/downl oad/29866 571b1bb20d986efd905ef7f 689141329

Eklundh, L., \& Jönsson, P. (2015). TIMESAT: a software package for time-series processing and assessment of vegetation dynamics. In C. Kuenzer, S. Dech, \& W. Wagner (Eds.), Remote sensing time series - revealing land surface dynamics (pp. 141-158). Lund: Springer International Publishing.

Grzegozewski, D. M., Johann, J. A., Uribe-Opazo, M. A., Mercante, E., \& Coutinho, A. C. (2016). Mapping soya bean and corn crops in the State of Paraná, Brazil, using EVI images from the MODIS sensor. International Journal of Remote Sensing, 37(6), 1257-1275. doi: 10.1080/01431161.2016.1148285
Instituto Brasileiro de Geografia e Estatística. (2002). Pesquisa Agropecuária. (Vol. 6). Recuperado de $\mathrm{ftp} / / / \mathrm{ftp}$. ibge.gov.br/Producao_Agricola/Producao da_Extracao_Vegetal_e_da_Silvicultura_[anual]/ Metodologia_da_Pesquisa/PesquisasAgropecuarias. pdf

Johann, J. A., Becker, W. R., Uribe-Opazo, M. A., \& Mercante, E. (2016). Estimating soybean development stages in Paraná State - Brazil through orbital modis images. Engenharia Agrícola, 36(1), 126-142. doi: 10.1590/1809-4430-Eng.Agric.v36n1p126-142/2016

Johann, J. A., Rocha, J. V., Duft, D. G., \& Lamparelli, R. A. C. (2012). Estimation of Summer Crop Areas in the State of Paraná, Brazil, Using Multitemporal EVI/Modis Images. Pesquisa Agropecuária Brasileira, 47(9), 1295-1306. doi: 10.1590/S0100204X2012000900015

Mathison, C., Deva, C., Falloon, P., \& Challinor, A. J. (2018). Estimating sowing and harvest dates based on the Asian summer monsoon. Earth System Dynamics, 9(2), 563-592. doi: 10.5194/esd-9-5632018

Ren, J., Campbell, J., \& Shao, Y. (2017). Estimation of SOS and EOS for Midwestern US corn and soybean crops. Remote Sensing, 9(7), 722. doi: 10.3390/ rs9070722

Richetti, J., Judge, J., Boote, K. J., Johann, J. A., Uribe-Opazo, M. A., Becker, W. R.,... Silva, L. C. de A. (2018). Using phenology-based enhanced vegetation index and machine learning for soybean yield estimation in Paraná State, Brazil. Journal of Applied Remote Sensing, 12(02), 1. doi: 10.1117/1. JRS. 12.026029

Secretaria da Agricultura e do Abastecimento/ Departamento de Economia Rural (2019). Divisão de Estatísticas Básicas - DEB. Recuperado de http:// www.agricultura.pr.gov.br/deral/safras

Souza, C. H. W. de, Mercante, E., Johann, J. A., Lamparelli, R. A. C., \& Uribe-Opazo, M. A. (2015). Mapping and discrimination of soya bean and corn crops using spectro-temporal profiles of vegetation indices. International Journal of Remote Sensing, 36(7), 1809-1824. doi: 10.1080/01431161.2015.102 6956

Terler, G., Gruber, L., \& Knaus, W. F. (2017). Effect of variety and harvest date on nutritive value and ruminal degradability of ensiled maize ears. Archives of Animal Nutrition, 71(5), 333-346. doi: 10.1080/ 1745039X.2017.1358537 
United States Departament of Agriculture. (2019). Wardlow, B. D., Kastens, J. H., \& Egbert, S. L. (2006). World Agricultural Production. 19(12). Retrieved from https://apps.fas.usda.gov/psdonline/circulars/ production.pdf.

Using USDA crop progress data for the evaluation of greenup onset date calculated from MODIS 250-Meter Data. Photogrammetric Engineering \& Remote Sensing, 72(11), 1225-1234. doi: 10.14358/ PERS.72.11.1225 